\title{
PHYSIOLOGICAL QUALITY OF MECHANICALLY HARVESTED CHICKPEA SEEDS
}

Letícia Betânia Xavier Dias $^{* *}$ (B), Pedro Afonso de Melo Queiroz ${ }^{2}$ (B), Thaís Cardoso de Castro ${ }^{3}$ (B), Marco Antonio Moreira de Freitas $^{4}$ (1) Érica Fernandes Leão-Araújo ${ }^{5}$ \& Warley Marcos Nascimento 6 (B)

\author{
* Autor correspondente \\ 1 - Bacharel em Agronomia, Instituto Federal Goiano - Campus Urutaí (IF Goiano), leticia_bxd@hotmail.com \\ 2 - Bacharel em Agronomia, Instituto Federal Goiano - Campus Urutaí (IF Goiano), pedro.melo.100@hotmail.com \\ 3 - Bacharel em Agronomia, Instituto Federal Goiano - Campus Urutaí (IF Goiano), thaiscdc@hotmail.com \\ 4 - Professor Dr. no Departamento de Agronomia do Instituto Federal Goiano - Campus Urutaí (IF Goiano), marco.freitas@ifgoiano.edu.br \\ 5 - Professora Dra. no Departamento de Agronomia do Instituto Federal Goiano - Campus Urutaí (IF Goiano), erica.leao@ifgoiano.edu.br \\ 6 - Chefe geral da Embrapa Hortaliças (CNPH). Brasília/DF, warley.nascimento@embrapa.br
}

\section{Keywords:}

Cicer arietinum $\mathrm{L}$.

Mechanical damage

Leached Exudates

Tetrazolium

Vigor

\section{ABSTRACT}

Our objective was to evaluate the occurrence of mechanical damage in chickpea seeds with the combination of two harvester speeds $\left(2.5\right.$ and $\left.3.5 \mathrm{~km} \cdot \mathrm{h}^{-1}\right)$ and three adjustments for rotor rotation speeds (500, 700, and $850 \mathrm{rpm})$. Harvesting was carried out in a seed production field. Seeds were evaluated for purity, germination $(\mathrm{G})$, first count (FC), germination speed index (GSI), hypochlorite, electrical conductivity, and tetrazolium tests. There was an effect of harvester speeds on seed physiological quality for the first count (FC), germination (G), germination speed index (GSI), especially when combining with high rotor rotation speed. In these cases, the speed of $2.5 \mathrm{~km} \cdot \mathrm{h}^{-1}$ resulted in lower values. This harvester speed also had worse results when combining with $850 \mathrm{rpm}$ for purity and hypochlorite tests. The tetrazolium test was not efficient in identifying differences in seed quality. There was no significant interaction between harvester speeds and rotor rotation speeds for the conductivity test. Evaluating the harvester speed's isolated effect $\left(3.5 \mathrm{~km} \cdot \mathrm{h}^{-1}\right)$, we identified problems in seed vigor due to the higher value of exudates in the electrical conductivity test. Low harvester speed $\left(2.5 \mathrm{~km} \cdot \mathrm{h}^{-1}\right)$ associated with high rotor rotation speeds (700 and $850 \mathrm{rpm}$ ) causes a reduction of the physical and physiological quality of seeds.

\section{Palavras-chave: \\ QUALIDADE FISIOLÓGICA DE SEMENTES DE GRÃO-DE-BICO COLHIDAS Cicer arietinum L. MECANICAMENTE}

Dano mecânico

Lixiviados

Tetrazólio

Vigor

\section{RESUMO}

Objetivou-se avaliar, duas velocidades de deslocamento da colhedora $\left(2,5\right.$ e 3,5 $\left.\mathrm{km} \mathrm{h}^{-1}\right)$ e três regulagens para rotações do rotor da trilha $(500,700$ e $850 \mathrm{rpm})$, na ocorrência de danos mecânicos em grãode-bico. A colheita foi realizada em campo de produção de sementes. As sementes foram avaliadas quanto à pureza, germinação $(\mathrm{G})$, primeira contagem (PC), índice de velocidade de germinação (IVG), teste de hipoclorito, teste de condutividade elétrica e teste de tetrazólio. Houve efeito da velocidade de deslocamento da máquina na qualidade fisiológica das sementes: primeira contagem (PC), germinação (G) e índice de velocidade de germinação (IVG) principalmente em altas rotações do rotor de trilha (700 e $850 \mathrm{rpm}$ ). Nestes casos, a velocidade de $2,5 \mathrm{~km} \mathrm{~h}^{-1}$ resultou em valores inferiores. Esta velocidade também revelou piores resultados com $850 \mathrm{rpm}$ para pureza e hipoclorito. O teste de tetrazólio não foi eficiente para identificar diferenças na qualidade das sementes. Não houve interação significativa entre velocidade de deslocamento e rotações do rotor para o teste de condutividade. A avaliação do efeito isolado da velocidade de deslocamento identificou que a $3,5 \mathrm{~km} \mathrm{~h}^{-1}$ há problemas no vigor das sementes pela maior liberação de exsudatos no teste de condutividade elétrica. Baixa velocidade de deslocamento da colhedora $\left(2,5 \mathrm{~km} \mathrm{~h}^{-1}\right)$ associadas à altas rotações do rotor de trilha (700 e $\left.850 \mathrm{rpm}\right)$ causam redução da qualidade física e fisiológica das sementes. 


\section{INTRODUCTION}

The chickpea is an annual legume, diploid ( $2 \mathrm{n}$ $=16$ ), autogamous, belongs to the Fabaceae family and genus Cicer. Its germination is of the hypogeal type and has a wide morphological variation due to genetic and environmental factors and their interaction (NASCIMENTO et al., 2016). It is predominantly cultivated as a post-rainy season crop on residual soil moisture and experiences progressive drought stress with varying intensity (KASHIWAGI et al., 2015). Even in adverse conditions, cultivation success depends mostly on the use of quality seeds in the field.

Regulation of the harvester components is one of the more significant factors in seed production. According to Chioderoli et al. (2012), the regulation must be adequate according to the culture, genetic material, water content of the grain, and purpose of the grains. Thus, with a well-regulated machine, the possibility of an injury occurring at the time of harvest is reduced, ensuring the seeds' vigor and viability. Mechanical injuries are sources of reduction in the seeds' physiological quality, affecting the embryo's nourishment or even making it unfeasible.

Both immediate and latent mechanical damage originates at the moment of threshing, that is, when considerable forces are applied to the seeds to separate them from the pods. This occurs mainly due to the cylinder's impact when the harvested material passes through the concave (HOLTZ; REIS, 2013).

According to Cunha et al. (2009), the axialflow combine harvesters -in which the material enters in the direction of the cylinder axis (called rotor)- allows a reduction of the mechanical damage indexes in comparison to the tangential feeding trail system. Thus, the operating speed of this rotor interferes with the amount of damage to the seeds. Also, the machine's speed can influence the amount of material that enters the cylinder and, consequently, affect the threshing process.

Mechanical damage is the primary source of deterioration of chickpea seeds since the embryonic region is highly exposed. The damages caused by mechanized harvesting can directly influence seeds' production, reduce their vigor, and make the germination process unfeasible. According to Puzzi (1989), broken and cracked grains are a source of deterioration for stored products, interfering with the final quality and reducing the percentage of germination and vigor.

França Neto (2009) explains that for the identification of damages, several tests can be carried out during seed quality control, such as the sodium hypochlorite test, which is the quickest way to evaluate seeds with mechanical damage. The tetrazolium test stands out due to its speed, precision, and the large number of information it provides; besides assessing feasibility and vigor, it shows possible causes for reducing the seed's quality, such as mechanical damage (FRANÇA NETO et al., 1998). Our objective was to evaluate the physical and physiological quality of mechanically harvested seeds under different harvester $\left(\mathrm{km} \mathrm{h}^{-1}\right)$ and rotor rotation speeds (rpm).

\section{MATERIAL AND METHODS}

The experiment was carried out in a commercial seed production field in the municipality of Cristalina-GO. We used a New Holland machine for harvesting, model CR 6080, 2011/2012, 30foot harvesting platform, $1050 \mathrm{rpm}$ fan adjustment, and automatic reel adjustment. Initially, we harvested the field border, and then combinations of the harvester speed $\left(2.5\right.$ and $\left.3.5 \mathrm{~km} \mathrm{~h}^{-1}\right)$ and rotor rotation speeds $(500,700$, and $850 \mathrm{rpm})$ were carried out. The harvester and rotor rotation speeds combinations resulted in six lots of chickpea seeds (Cicer arietinum L.), cultivar Cícero, mechanized harvested. The samples for each combination were obtained from the harvester reservoir - located next to the control cabin - until totaling an approximate volume of 2 kilograms for the average lot sample. The collection of 20 simple samples at regular intervals during harvest makes up the average sample.

Six seed lots were obtained, each combination having one respective lot. The seeds' physical and physiological quality analyses were carried out at the Seed Analysis Laboratory of the Agronomy Department of the Federal Goiano Institute, Campus Urutaí.

The lots were kept in kraft paper bags and 
stored in a cold chamber $\left(16{ }^{\circ} \mathrm{C}\right.$ and $50-60 \%$ relative humidity) in the laboratory. The lots had their moisture content and purity determined, and physiological quality tests performed. The methodologies are described below:

Moisture content was determined by the greenhouse method at $105 \pm 3{ }^{\circ} \mathrm{C} / 24 \mathrm{~h}$ (BRASIL, 2009), using two subsamples of 10 seeds from each lot. The results were expressed as a percentage (wet weight basis).

Germination $(\mathrm{G})$ : four replicates of 50 seeds per lot were distributed under two germination towel paper, and over the seeds, another tower paper, finally they were rolled firmly. The papers were previously moistened with the equivalent of 3.0 times the weight of the dry substrate. The rolls were kept in a Mangelsdorf type germinator at 20 ${ }^{\circ} \mathrm{C}$ for five days when the first count (FC) data were registered. Eight days after sowing, the final germination data were obtained. The results were expressed as a percentage of normal seedlings.

Germination speed index (GSI): conducted along with the germination test, noting the number of normal seedlings every 24 hours until the 8th day after sowing.

Purity (Pure): four 500g subsamples of the average sample. The seed was considered as pure if it was the same species (C. arietinum), mature, whole, or damaged, as long as there was more than half of their initial reserve. 'Other seeds' group included the dispersion units of any plant species other than that of the pure seed. The 'Inert material' group contained the dispersion units and all other materials and structures not defined as pure seed or other seeds (BRASIL, 2009). The result was expressed as the average of the repetitions in mass (g) of pure seeds.

Sodium hypochlorite (SH): we used a methodology similar to soybean culture, in which 25 $\mathrm{mL}$ of sodium hypochlorite stock solution $(5.25 \%)$ was added to $975 \mathrm{~mL}$ of water. Two repetitions of 100 seeds were immersed in the solution for 10 minutes. After this period, we removed the seeds from the solution and evaluated the seeds that were soaked, indicative of mechanical injury (KRZYZANOWSKI et al., 2004). The results were expressed as an average percentage of seeds with mechanical injury per lot.
Electrical conductivity (EC): the test was conducted with four subsamples of 75 seeds for each lot, weighed with a precision of 0.0001 $\mathrm{g}$, placed in plastic cups containing $100 \mathrm{~mL}$ of deionized water, according to the methodology recommended by Dias et al. (2019). The electrical conductivity of the solution, maintained at $25^{\circ} \mathrm{C}$, was evaluated after 24 hours. The electrical conductivity was determined with a conductivity meter and the values expressed in $\mu \mathrm{S} . \mathrm{cm}^{-1} \cdot \mathrm{g}^{-1}$ of seeds.

Tetrazolium(TZ): performed with four replicates of 25 seeds preconditioned on germination paper, moistened and folded, wrapped in a polyethylene envelope, and kept at room temperature $\left(41^{\circ} \mathrm{C} \pm\right.$ $2)$, for 6 hours. The seeds were kept submerged in a tetrazolium solution $(0.1 \%)$, placed in $50 \mathrm{~mL}$ polyethylene cups, kept at $30^{\circ} \mathrm{C}$ for six hours, and evaluated individually. For the evaluations, cuts were made through the embryonic axis to observe the color differentiation of the tissues, as follows: a) carmine red - vivid and vigorous tissue; b) intense red - deteriorating tissue; and c) milky white dead tissue. The location of the damage was also considered for the classification of seeds in vigor levels. We used the classification suggested by Paraíso et al. (2019), seeds of classes I, II, and III (TZ viab) were considered viable and only classes I and II were considered to be vigorous (TZ vig).

The experiment was carried out in a completely randomized design in a split-plot design, the plots being the harvester speed and the subplots the rotor rotation speeds, with four replicates. The coefficients of variation $(\mathrm{CV} \%)$ of the variables were calculated according to the equation 1 :

$C V=\frac{S D}{\text { mean }} \times 100$.

Where SD is equal to Standard Deviation. The residues were tested for normality and homoscedasticity. The data were subjected to analysis of variance by the F-test, and to compare the mean, a test of means at $5 \%$ probability was used.

\section{RESULTS AND DISCUSSION}

The average values of seeds' moisture content 
for each treatment varied between 7.9 to $13.1 \%$. Through the purity tests, sodium hypochlorite, first germination count, germination, and germination speed index, there was a significant interaction with the harvester and rotor rotation speeds (Table 1 and Table 2).

The purity test indicates how the combination of harvester and rotor rotation speeds influence mechanical damages during the harvesting operation. Cassia et al. (2015) tested two similar harvesters with different cylinder clearance and rotor rotation settings and obtained purity of approximately $99 \%$ for at least of the combinations, meaning that it is possible to obtain seed lots with low rates of mechanical damage from mechanical harvesting.

The combination of the harvester speed of $3.5 \mathrm{~km} . \mathrm{h}^{-1}$ and rotor rotations at $500 \mathrm{rpm}$ had the lowest value of pure seeds (Table 1). According to Silva et al. (2013a), the increase in harvester speed was accompanied by an increase in the percentage of broken seeds (splits) in soybean lots, resulting in a lower percentage of pure seeds. Analyzing the speed of $2.5 \mathrm{~km} \cdot \mathrm{h}^{-1}$, the lowest number of pure seeds occurred at the highest speed of $850 \mathrm{rpm}$. It may have happened because, at a lower harvester

Table 1. Physiological quality of chickpea seeds results for purity (Pure), sodium hypochlorite (SH) tests. Urutaí, 2020

\begin{tabular}{|c|c|c|c|c|c|c|}
\hline \multirow{3}{*}{ Rotor Rotations Speed (rpm) } & \multicolumn{2}{|c|}{ Pure } & \multicolumn{4}{|c|}{ SH } \\
\hline & \multicolumn{2}{|c|}{ Harvester Speed $\left(\mathrm{km} \mathrm{h}^{-1}\right)$} & \multicolumn{4}{|c|}{ Harvester Speed $\left(\mathrm{km} \mathrm{h}^{-1}\right)$} \\
\hline & 2.5 & 3.5 & \multicolumn{2}{|c|}{2.5} & \multicolumn{2}{|c|}{3.5} \\
\hline & \multicolumn{2}{|c|}{$\mathrm{g}$} & \multicolumn{4}{|c|}{$\%$} \\
\hline 500 & $490.31 \mathrm{aA}$ & $479.61 \mathrm{bB}$ & 3.25 & $\mathrm{aA}$ & 5.75 & $\mathrm{bA}$ \\
\hline 700 & $486.15 \mathrm{aB}$ & $485.59 \mathrm{aA}$ & 4.25 & $\mathrm{aA}$ & 5.25 & $\mathrm{aA}$ \\
\hline 850 & $479.89 \mathrm{aC}$ & $482.82 \mathrm{aAB}$ & 7.75 & $\mathrm{bB}$ & 4.25 & $\mathrm{aA}$ \\
\hline CV plot (\%) & \multicolumn{2}{|c|}{0.59} & \multicolumn{4}{|c|}{24.31} \\
\hline CV subplot (\%) & \multicolumn{2}{|c|}{0.44} & \multicolumn{4}{|c|}{35.61} \\
\hline p-valor plot & \multicolumn{2}{|c|}{0.0542} & \multicolumn{4}{|c|}{1.0000} \\
\hline p-valor subplot & \multicolumn{2}{|c|}{0.0025} & \multicolumn{4}{|c|}{0.2467} \\
\hline p-valor interaction & \multicolumn{2}{|c|}{0.0000} & \multicolumn{4}{|c|}{0.0160} \\
\hline
\end{tabular}

Means followed by the same letter, lower case on the line and upper case on the column, do not differ by Tukey's test at 5\% probability

Table 2. Physiological quality of chickpea seeds results for first germination count (FC), germination (G), and germination speed index (GSI) tests. Urutaí, 2020

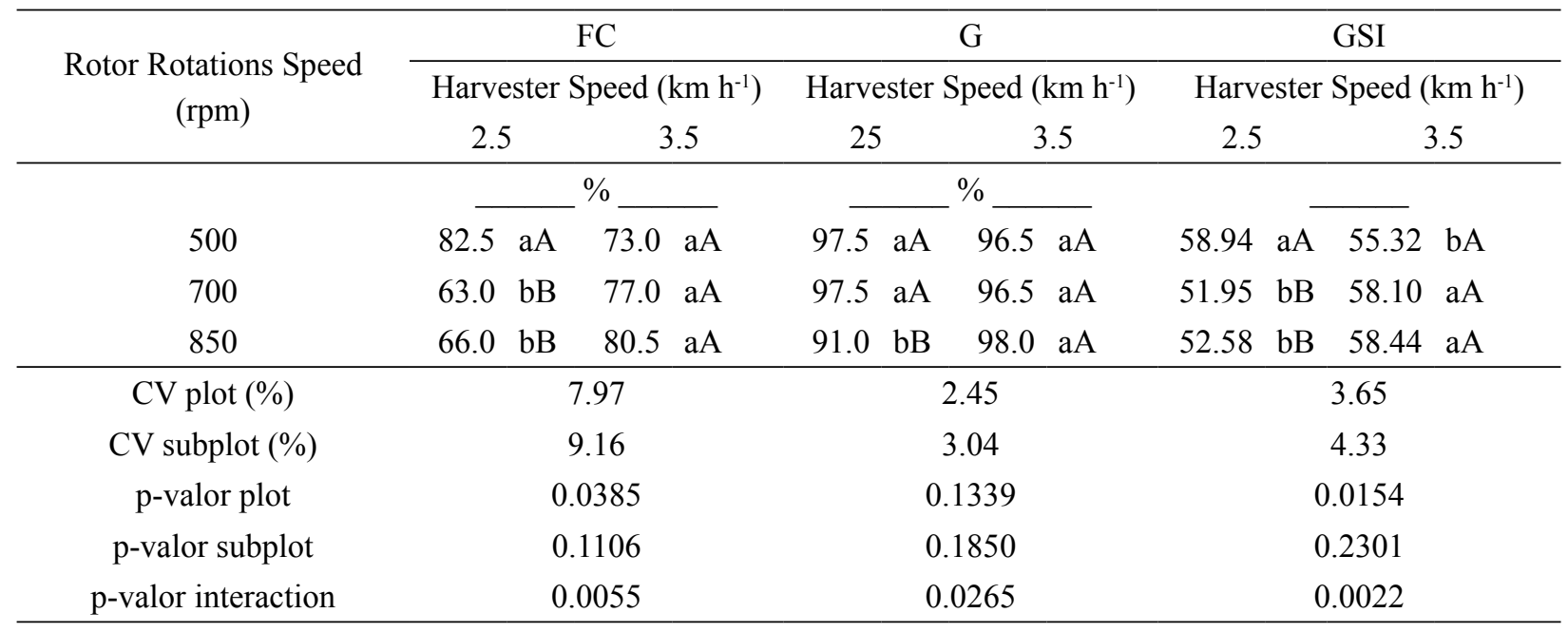

Means followed by the same letter, lower case on the line and upper case on the column, do not differ by Tukey's test at $5 \%$ probability 
speed and higher rotations of the cylinder allow for more impacts and attrition of the seeds against the structures of the harvester's threshing system due to the reduction of the feed and load of the threshing system, thus increasing the mechanical damages and then reducing the mass of pure seeds in the lot.

The SH and G tests showed a high incidence of mechanical damage for the seed lot under the combination of low harvester speed $\left(2.5 \mathrm{~km} . \mathrm{h}^{-}\right.$ $\left.{ }^{1}\right)$ and high rotor rotation speed (850rpm), which can be verified in the SH data (Table 1). At higher rotor rotations, the collision of the seed with the harvester's structures (cutting, trail, and separation systems) causes breakage along the cotyledon part and, therefore, increasing the percentage of splits (cotyledons) (SILVA et al., 2013a).

In the FC and GSI tests, it was observed that the lowest travel speed $\left(2.5 \mathrm{~km} \cdot \mathrm{h}^{-1}\right)$, in combination with 700 and $850 \mathrm{rpm}$ rotation speeds, affected the seed's vigor. One of the first effects of the decrease in seed physiological quality is the reduction of the germination speed process; as the first count test evaluates the speed of this process, the test can be used as a good indicator of the seeds' vigor (MARCOS-FILHO, 2015; DIAS et al., 2019).

The GSI test is among the most well-known vigor tests, and it is easy to perform since the data collection is collected during the germination test itself. Tests based on germination speed relate to the fact that lots in which seeds germinate faster have high vigor, thus having a direct relationship between germination speed and seed vigor (SMANIOTTO et al., 2014). Vigorous seeds can establish and form seedlings quickly, while those with mechanical damage or other damage take longer to complete the germination process's tasks.

Comparing the six harvester combinations with seed physiological quality tests, we observed that the speed of $2.5 \mathrm{~km} \cdot \mathrm{h}^{-1}$ associated with 700 and 850 rpm presented lower FC and GSI values, but the G and $\mathrm{SH}$ tests did not have the worst performances. These variations in the physiological quality tests results may have happened due to the greater precision to detect small differences in the seeds' quality with the vigor tests contrary to faster tests such as $\mathrm{SH}$, which may not be sensitive to detect such differences. Besides, the germination test evaluates the viability of seeds in optimal conditions, which can also favor the non-detection of subtle differences in deterioration.

In general, the best results for all tests were obtained with the lowest harvester speed tested $\left(2.5 \mathrm{~km} \cdot \mathrm{h}^{-1}\right)$ associated with the lowest rotation (500 rpm). It can be explained by the fact that the impacts suffered by the seeds are reduced in these conditions, both on the platform during harvest and the threshing process.

Maize researches described that as the harvester speed increases, the losses decrease until reaching an optimal point. After that point, the machine's increase in speed causes a more substantial impact on the plant, causing the ear to detach from the plant and be thrown out of the harvest platform (ZERBATO et al., 2013). High values of rotor rotations also result in significant losses (VENEGAS et al., 2012). For soybeans, the higher speed allows a significant impact of the pods on the bar mower, leading to a greater number of opened pods at that moment when compared to slower speeds (CAMOLESE et al., 2015). Thus, for the chickpeas is also recommended lower harvester and rotor rotation speeds.

On the other hand, the lower harvester speed $\left(2.5 \mathrm{~km} \cdot \mathrm{h}^{-1}\right)$, when associated with the higher rotor rotation $(850 \mathrm{rpm})$, caused high mechanical damage, evidenced in the $\mathrm{SH}$ test, which had the worst result. The same trend occurred in the physiological quality tests (FC, G, and GSI), obviously as a reflection of the damage caused during harvest, in which the lower harvester speed reduced the volume of material in the platform and the threshing system. The free space in the machine may have aggravated the occurrence of injuries in the seeds, increasing the impacts of the seeds on the harvester's metallic structures.

The opposite was observed for the combination of $3.5 \mathrm{~km} \cdot \mathrm{h}^{-1}$ and $500 \mathrm{rpm}$, which caused the highest mechanical damage rates, based on the lowest pure seeds' values. These adjustments overload the entry of the threshing system, causing a deficiency. Although they do not differ statistically, lower seed vigor rates were observed in the GSI test, and a higher incidence of mechanical damage was demonstrated in the SH test. According to Paixão et al. (2017), high rotor rotations were chosen at higher harvester speeds because, with the increase in speed, more material is harvested, and, therefore, it was necessary to increase the rotation of the cylinders. Thus, the speed of $3.5 \mathrm{~km} \cdot \mathrm{h}^{-1}$, when 
associated with higher rotor rotation speeds $(850$ $\mathrm{rpm}$ ), can offer more satisfactory results.

For the tetrazolium and electrical conductivity tests (Table 3), there was no significant interaction with the harvester speed and the number of rotor rotations. Thus, we analyzed the simple effect of each of these variables. However, for the tetrazolium test, there was also no interaction for the simple effect of the variables.

In similar studies, Bornhofen et al. (2015) explain that this probably occurred due to damage to the integument resulting from alternate exposure to wet and dry environmental conditions during the physiological post-maturity period. These results reflect the lower percentage of normal seedlings during germination $(\mathrm{G})$, and the loss of seeds' viability was due to damage caused to the embryonic axis (Figure 1), it being essential for their normal development.

The tetrazolium test was not efficient in

Table 3. Average percentage of the tetrazolium test for viability ( $\mathrm{TZ}$ viab) and vigor (TZ vig) and electrical conductivity test (EC) results as a function of the track rotor rotations (rpm) and the harvester speeds $\left(\mathrm{km} \cdot \mathrm{h}^{-1}\right)$

\begin{tabular}{|c|c|c|c|c|c|c|}
\hline \multirow[b]{2}{*}{ Rotor Rotations Speed (rpm) } & \multicolumn{2}{|c|}{ TZ viab } & \multicolumn{2}{|c|}{ TZ vig } & \multicolumn{2}{|c|}{$\mathrm{EC}$} \\
\hline & \multicolumn{3}{|c|}{$\%$} & & \multicolumn{2}{|c|}{$\mu \mathrm{cm}^{-1} \mathrm{~g}^{-1}$} \\
\hline 500 & 99 & $\mathrm{a}$ & 75.0 & $\mathrm{a}$ & 55.9 & a \\
\hline 700 & 99 & $\mathrm{a}$ & 66.0 & $\mathrm{a}$ & 58.3 & $a$ \\
\hline 850 & 99 & $\mathrm{a}$ & 68.5 & $\mathrm{a}$ & 61.2 & $\mathrm{a}$ \\
\hline \multicolumn{7}{|l|}{ Harvester Speed $\left(\mathrm{km} \mathrm{h}^{-1}\right)$} \\
\hline 2.5 & 100 & $\mathrm{a}$ & 75.0 & $\mathrm{a}$ & 54.6 & $\mathrm{a}$ \\
\hline 3.5 & 98 & $\mathrm{a}$ & 64.6 & $\mathrm{a}$ & 62.3 & $\mathrm{~b}$ \\
\hline CV plot (\%) & \multicolumn{2}{|c|}{1.35} & \multicolumn{2}{|c|}{23.18} & \multicolumn{2}{|c|}{9.46} \\
\hline CV subplot (\%) & \multicolumn{2}{|c|}{3.93} & \multicolumn{2}{|c|}{18.89} & \multicolumn{2}{|c|}{11.08} \\
\hline p-valor plot & \multicolumn{2}{|c|}{1.0000} & \multicolumn{2}{|c|}{0.5351} & \multicolumn{2}{|c|}{0.1983} \\
\hline p-valor subplot & \multicolumn{2}{|c|}{0.2544} & \multicolumn{2}{|c|}{0.1034} & \multicolumn{2}{|c|}{0.0273} \\
\hline p-valor interaction & \multicolumn{2}{|c|}{1.0000} & \multicolumn{2}{|c|}{0.9824} & \multicolumn{2}{|c|}{0.1725} \\
\hline
\end{tabular}

Means followed by the same letter do not differ by Tukey's test at $5 \%$ probability

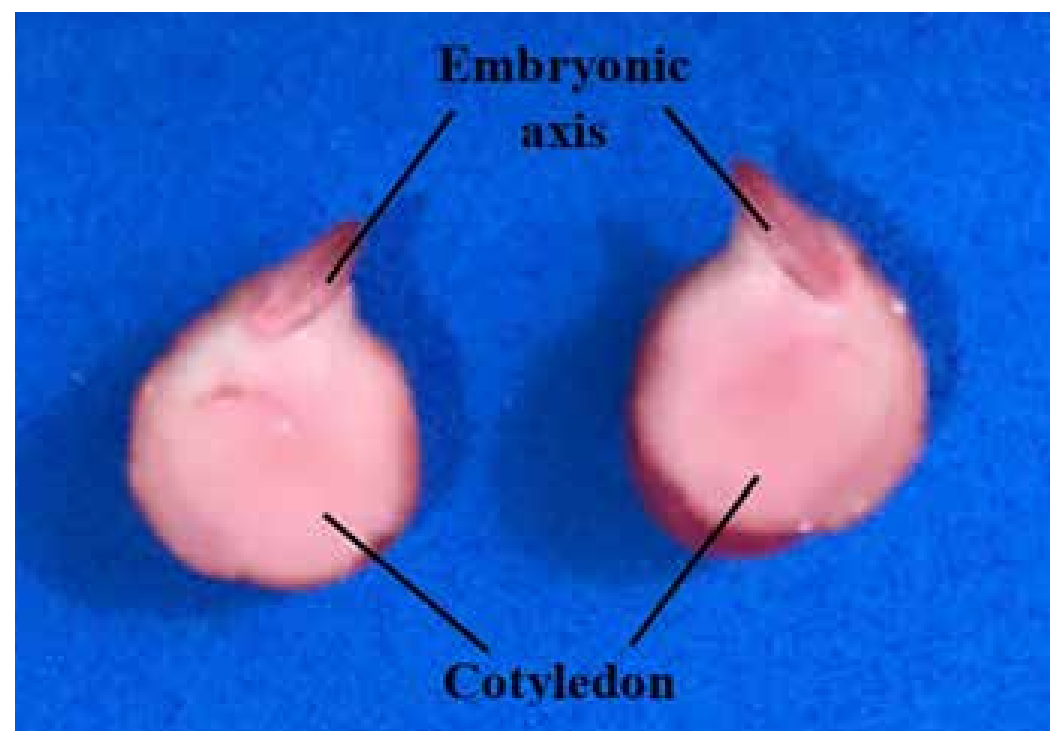

Figure 1. Separated cotyledons of chickpea seeds colored with a tetrazolium salt and indicated embryonic axis. Urutaí, 2020 
differentiating the lots' physiological quality (combinations of rotor rotations and harvester speed), so that not even the assessments of viability and vigor showed differences for these conditions. This test characterizes as a visual test, thus subjected to subjective evaluations, despite having recent described a methodology for the studied species (PARAIISO et al., 2019). Further studies for the adequacy of the methodology are necessary to obtain satisfactory results as those obtained for other crops, such as soybean, in which it is a standard test, extremely sensitive, and used regularly. Other species also have their appropriate methodologies, such as sunflower (SILVA et al., 2013b), cowpea (RODRIGUES et al., 2015), and crambe (REZENDE et al., 2015).

There was no significant interaction for the conductivity test (EC) nor even a significant effect when analyzing the rotor rotations' simple effect. However, the evaluation of the isolated effect of the harvester speed identified that at $3.5 \mathrm{~km} . \mathrm{h}^{-1}$ there are problems in the seed vigor because of the greater release of exudates, and the same happened for the Purity, SH, and GSI test when combined with low rotor rotations speed $(500 \mathrm{rpm})$.

\section{CONCLUSION}

- Low harvester speed $\left(2.5 \mathrm{~km} \cdot \mathrm{h}^{-1}\right)$ associated with high rotor rotations (700 and 850 rpm) causes a reduction in the physical and physiological quality of chickpea seeds.

- The most suitable combination is a harvester speed at $2.5 \mathrm{~km} \cdot \mathrm{h}^{-1}$ and the rotor rotations speed at $500 \mathrm{rpm}$.

\section{AUTHORSHIP CONTRIBUTION STATEMENT}

DIAS, L.B.X.: acquisition of data, analysis and interpretation of data, drafting and revising the work; QUEIROZ, P.A.M.: acquisition of data, analysis and interpretation of data, revising the work; DE CASTRO, T.C.: acquisition of data, analysis and interpretation of data, revising the work; DE FREITAS, M.A.M.: analysis and interpretation of data, drafting and revising the work; LEÃOARAÚJO, E.F.: supervision and conception of the research, analysis and interpretation of data, drafting and revising the work; NASCIMENTO, W.M.: conception of the research, drafting and revising the work.

\section{DECLARATION OF INTERESTS}

The authors declare that they have no known competing financial interests or personal relationships that could have appeared to influence the work reported in this paper.

\section{ACKNOWLEDGE}

We thank the Federal Institute of Science and Technology - Campus Urutaí, for helping with scientific publication and granting scholarships to the first author.

\section{REFERÊNCIAS BIBLIOGRÁFICAS}

BORNHOFEN E; BENIN, G.; GALVAN, D.; FLORES, M. F. Épocas de semeadura e desempenho qualitativo de sementes de soja. Pesquisa Agropecuária Tropical, Goiânia, v. 45, n. 1, p. 46-55, 2015.

BRASIL - Ministério da Agricultura, Pecuária e Abastecimento, Secretaria de Defesa Agropecuária. Regras para análise de sementes. Brasília, DF, 2009.

CAMOLESE, H. S.; BAIO, F. H. R.; ALVES, C. Z. Perdas quantitativas e qualitativas de colhedoras com trilha radial e axial em função da umidade do grão. Brazilian Journal of Biosystems Engineering, Tupã, v. 9, n.1, p. 21-29, 2015.

CASSIA, M. T.; VOLTARELI, M. A.; SILVA, R. P.; ZERBATO, C.; LIMA, P. H. Monitoramento da operação de colheita mecanizada de sementes de soja. Revista Brasileira de Engenharia Agrícola e Ambiental, Campina Grande, v. 19, n. 12, p. 1209-1214, 2015.

CHIODEROLI, C. A.; SILVA, R. P.; NORONHA, R. H. F.; CASSIA, M. T.; SANTOS, E. P. Perdas de grãos e distribuição de palha na colheita mecanizada de soja. Bragantia, Campinas, v.71, n.1, p. 112121, 2012.

CUNHA, J. P. A. R. DA; PIVA, G.; DE OLIVEIRA, C. A. A. Efeito do sistema de trilha e da velocidade das colhedoras na qualidade de sementes de soja. Bioscience Journal, Uberlândia, v. 25, n. 4, p. 3742, 2009. 
DIAS, L. B. X.; QUEIROZ, P. A. M.; FERREIRA, L. B. S.; SANTOS, W. V.; FREITAS, M. A. M.; SILVA, P. P.; NASCIMENTO, W. M.; LEÃOARAÚJO, E. F. Teste de condutividade elétrica e embebição de sementes de grão-de-bico. Revista Brasileira de Ciências Agrárias, Recife, v. 14, n. 2, p. 1-8, 2019.

FRANÇA-NETO, J. B.; KRZYZANOWSKI, F.C.; DA COSTA, N.P. O teste de tetrazólio em sementes de soja. Londrina: EMBRAPA - CNPSo, 1998.

FRANÇA-NETO, J. B. Evolução do conceito de qualidade de sementes. Londrina: Informativo Abrates, 2009.

HOLTZ, V.; DOS REIS, E. F. Perdas na colheita mecanizada de soja: uma análise quantitativa e qualitativa. Revista Ceres, Viçosa, v. 60, n.3, p. 347-353, 2013.

KASHIWAGI, J.; KRISHNAMURTHY, L.; PURUSHOTHAMAN, R.; UPADHYANA, $\mathrm{H}$. D.; GAUR, P. M.; GOWDA, C. L. L.; ITO, Q.; VARSHNEY, R. K. Scope for improvement of yield under drought through the root traits in chickpea (Cicer arietinum L.). Field Crops Research, Amsterdam, v. 170, p. 47-54, 2015.

KRZYZANOWSKI, F. C.; FRANÇA NETO, J. DE B.; DA COSTA, N. P. Teste de Hipoclorito de Sódio para Semente de Soja. Londrina: EMBRAPA - CNPSo, 2004.

MARCOS-FILHO, J. Fisiologia de sementes de plantas cultivadas. Londrina: ABRATES, 2015.

NASCIMENTO, W. M.; SILVA, P. P.; ARTIAGA, O. P. SUINAGA, F. A. Grão-de-bico. In: Nascimento WM (ed) Hortaliças Leguminosas. Embrapa: Brasília, 2016.

PAIXÃO, C. S. S.; CHRISPIN, C. P.; SILVA, R. P.; GIRIO, L. A. S.; VOLTARELLI, M. A. Physical and physiological quality of soybean seeds at three speeds of the harvester. Revista Brasileira de Engenharia Agrícola e Ambiental, Campina Grande, v. 21, n. 3, p. 214-218, 2017.

PARAÍSO, H. A.; JUNIOR, D. S. B.; AVELAR, R. I. S.; COSTA, C. A.; GOMES, L. S. P.; NASCIMENTO, W. M. Adjustments in the tetrazolium test methodology for assessing the physiological quality of chickpea seeds. Journal of Seed Science, Londrina, v.41, n.1, p. 007-012, 2019.

PUZZI, D. Abastecimento e armazenagem de grãos. Campinas: Instituto Campineiro de Ensino Agrícola, 1989.

REZENDE, R. G.; JESUS, L. L.; NERY, M. C.; ROCHA, A. S. Teste de tetrazólio em sementes de crambe. Semina: Ciências Agrárias, Londrina, v. 36, n. 4, p. 2539-2544, 2015.

RODRIGUES, A. P. M. DOS S.; JÚNIOR, A. F. M.; TORRES, S. B.; NOGUEIRA, N. W.; FREITAS, R. M. O. Teste de tetrazólio para avaliação da qualidade fisiológica de sementes de Vigna unguiculata (L.) Walp. Revista Ciência Agronômica, Fortaleza, v. 46, n. 3, p. 638-644, 2015.

DA SILVA, R. P. Perdas qualitativas na colheita mecanizada de sementes de soja. Semina: Ciências Agrárias, Londrina, v. 34, n. 2, p. 477-484, $2013 \mathrm{a}$.

DA SILVA, R. C.; GRZYBOWSKI, C. R. S.; FRANCA-NETO, J. B.; PANOBIANCO, M. Adaptação do teste de tetrazólio para avaliação da viabilidade e do vigor de sementes de girassol. Pesquisa agropecuária brasileira, Brasília, v. 48, n. 1, p. 105-113, 2013b.

SMANIOTTO, T. A. DE S.; RESENDE, O.; MARÇAL, K. A. F.; OLIVEIRA, D. E. C.; SIMON, G. A. Qualidade fisiológica das sementes de soja armazenadas em diferentes condições. Revista Brasileira de Engenharia Agrícola e Ambiental, Campina Grande, v. 18, n. 4, p. 446-453, 2014.

VENEGAS, F.; GASPARELLO, A. V.; DE ALMEIDA, M. P. Determinação de perdas na colheita mecanizada do milho (Zea mays L.) utilizando diferentes regulagens de rotação do cilíndro trilhador da colheitadeira. Ensaios e Ciência: Ciências Biológicas, Agrárias e da Saúde, Valinhos, v. 16, n. 5, p. 43-55, 2012.

ZERBATO, C.; CAVICHIOLI, F. A.; RAVELI, M. B.; MARRAFON, M.; SILVA, R. P. Controle estatístico de processo aplicado à colheita mecanizada de milho. Engenharia na Agricultura, Viçosa, v. 21 n. 3, p. 261-270, 2013. 